\title{
Analisis Kekuatan Konstruksi Sekat Melintang Kapal Tanker dengan Metode Elemen Hingga
}

\author{
Ardianus, Septia Hardy Sujiatanti, dan Dony Setyawan \\ Departemen Teknik Perkapalan, Fakultas Teknologi Kelautan, Institut Teknologi Sepuluh Nopember \\ (ITS) \\ e-mail:septi@na.its.ac.id,dony@na.its.ac.id
}

\begin{abstract}
Abstrak-Dalam proses desain kapal khususnya kapal niaga sangat dibutuhkan perhitungan kekuatan dan pemilihan konstruksi yang kokoh dan kuat. Perbedaan jenis konstruksi pada kapal mempengaruhi nilai kekuatan kapal dalam mengangkut muatan. Salah satu perbedaan jenis konstruksi berada pada jenis sekat yang digunakan yaitu corrugated bulkhead dan transverse bulkhead. Pemilihan jenis konstruksi sekat ini tentunya mempunyai nilai kekuatan yang berbeda. Analisis konstruksi sekat dilakukan dengan mengkonversi corrugated bulkhead ke transverse bulkhead dengan modulus penampang dan panjang elemen yang sama. Corrugated bulkhead divariasikan pada sudut yang berbeda dan transverse bulkhead berupa penguat horizontal atau penumpu. Kemudian dilakukan pemodelan dan analisis kekuatan konstruksi menggunakan finite element software. Sehingga mendapatkan perbandingan nilai kekuatan konstruksi masing-masing sekat. Dari hasil analisis didapatkan nilai, corrugated bulkhead mempunyai kekuatan lebih besar serta berat konstruksi yang lebih ringan dibandingkan dengan transverse bulkhead. Tegangan terkecil berada pada corrugated bulkhead sudut $45^{\circ}$ yaitu76.6 N/mm $\mathbf{m}^{2}$ dan tegangan terbesar pada Transverse bulkhead tanpa penumpu yaitu $145 \mathrm{~N} / \mathrm{mm}^{2}$. Deformasi terkecil pada corrugated bulkhead existing yaitu $2.48 \mathrm{~mm}$ dan deformasi terbesar pada transverse bulkhead tanpa penumpu yaitu 6.64 mm. Berat konstruksi terkecil pada corrugated bulkhead existing yaitu 38.1 ton dan berat konstruksi terbesar pada transverse bulkhead tanpa penumpu sebesar 49.5 ton. Konstruksi sekat yang paling murah adalah corrugated bulkhead sudut $64.36^{\circ}$ (existing) dikarenakan mempunyai berat konstruksi terkecil dan nilai tegangan $85.4 \mathrm{~N} / \mathrm{mm}^{2}$ yang masih memenuhi tegangan ijin.a pada konstruksi corrugated bulkhead existing yaitu sebesar 38.1 ton.
\end{abstract}

Kata Kunci-Corrugated bulkhead, finite element software, kekuatan konstruksi, transverse bulkhead.

\section{PENDAHULUAN}

$\mathrm{K}$ APAL merupakan alat transportasi laut yang mampu membawa muatan berupa barang dan penumpang dengan jumlah yang besar dibanding transportasi lainnya. Berdasarkan dari fungsi kapal tersebut khususnya pada kapal niaga sangat diperhatikan dari segi kekuatan konstruksi untuk bisa beroperasi dengan waktu yang lama serta dengan lingkungan yang cepat berubah. Dengan berkembangnya teknologi dibidang konstruksi kapal,pemilihan desain dan material sesuatu yang sangat dipertimbangkan oleh perusahaan galangan kapal dalam dalam perancangan dan pembuatan kapal baru. Salah satunya adalah sekat kedap air. Pada kapal tangki, sekat kedap air merupakan sekat pemisah antara muatan satu dengan muatan lainnya. Sekat kedap ini terdiri dari dua bagian, yaitu sekat kedap melintang dan sekat kedap membujur. Biasanya paling sering dijumpai adalah sekat melintang (tranverse bulkhead) yang terdiri dari pelat berpenegar atau pelat yang diberi penguat penegar (stiffener).

\section{TINJAUAN PUSTAKA}

\section{A. Modulus Penampang Sekat bergelombang}

Modulus penampang pada elemen corrugated bulkhead dapat ditentukan menggunakan aturan Biro Klasifikasi Indonesia tahun 2014 volume II tahun 2014 [1]. Modulus penampang sesungguhnya dari elemen sekat bergelombang dihitung sesuai rumus berikut :

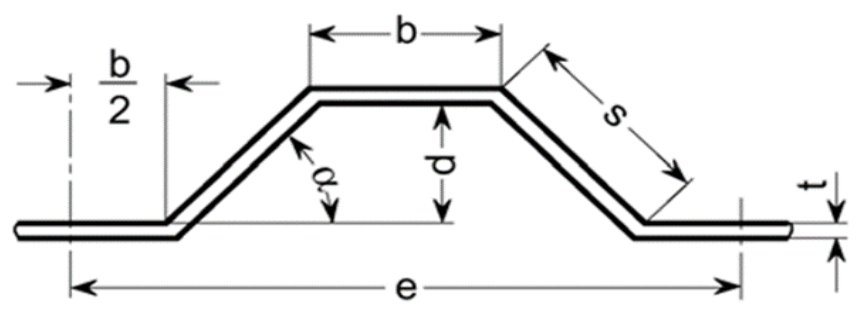

Gambar 1. Elemen Sekat Bergelombang

$$
\mathrm{W}=\mathrm{t} \cdot \mathrm{d}(\mathrm{b}+\mathrm{s} / 3)
$$

$$
\begin{aligned}
& \text { Dimana: } \\
& \mathrm{e} \quad=\text { lebar elemen }(\mathrm{cm}) \\
& \mathrm{b} \quad=\text { lebar pelat hadap }(\mathrm{cm}) \\
& \mathrm{s} \quad=\text { lebar pelat bilah }(\mathrm{cm}) \\
& \mathrm{d} \quad=\text { jarak antara pelat hadap }(\mathrm{cm}) \\
& \mathrm{t} \quad=\text { tebal pelat }(\mathrm{cm})
\end{aligned}
$$

\section{B. Sekat Melintang (Transverse Bulkhead)}

Pada umumnya sekat-sekat dibuat dari beberapa lajur pelat yang disusun secara mendatar sampai geladak lambung timbul. Untuk penguatan pelat sekat dipasang penegar-penegar yang dipasang secara mendatar. Di samping itu sekat melintang dapat pula dibuat dari pelat bergelombang tanpa penegar. Ujung-ujung penegar dapat diikat dengan pelat lutut, dengan mengelaskan langsung pada geladak dan dasar ganda atau membiarkan penegar tanpa pengikatan kecuali penegar yang dihubungkan dengan penumpu geladak dan penumpu 
samping alas [2].
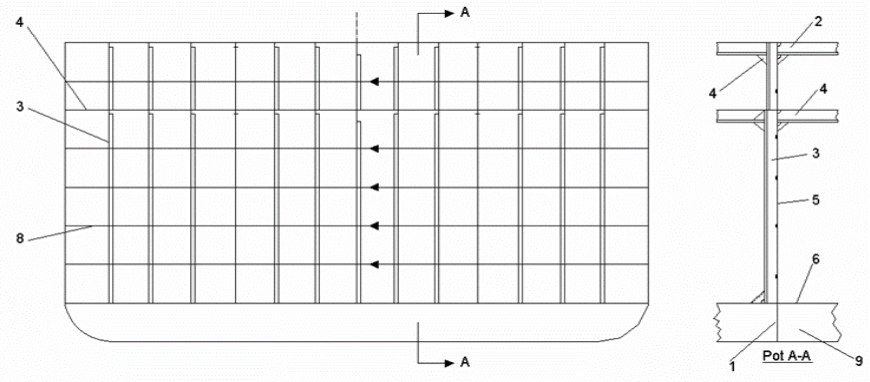

Gambar 2. Sekat Transverse Bulkhead

\section{Sekat Bergelombang (Corrugated Watertight Bulkhead)}

Sekat bergelombang (corrugated bulkhead), yaitu jenis sekat yang tidak memiliki penegar-penegar. Sekat ini terdiri dari beberapa bagian elemen pelat yang mempunyai lekukan (gelombang) dan disambung dengan system pengelasan. Sudut-sudut elemen pelat gelombang (alpha) minimum $45^{\circ}$.

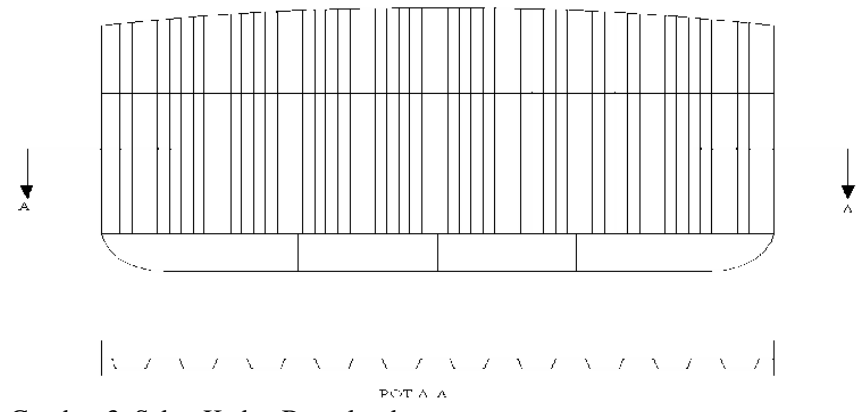

Gambar 3. Sekat Kedap Bergelombang

\section{Metode Elemen Hingga}

Persoalan perancangan dapat diselesaikan dengan cara matematis dan numeris. Untuk benda-benda yang mempunyai bentuk yang tidak teratur (elemen isoparametrik), penyelesaiannya akan sulit menggunakan cara matematis. Sehingga perlu digunakan cara numerik, yang dalam perkembangannya disebut sebagai Metode Elemen Hingga (Finite Elements Method). Bila suatu kontinu dibagi-bagi menjadi beberapa bagian yang lebih kecil (subregion) maka bagian-bagian kecil ini disebut elemen hingga. Proses pembagian suatu kontinu menjadi elemen hingga ini dikenal sebagai proses pembagian (deskritisasi), sehingga elemen hingga merupakan pendekatan bagian demi bagian dengan menggunakan polinomial yang mana masingmasing terdefinisi pada daerah (elemen) yang kecil dan dinyatakan dalam harga-harga titik simpul dari fungsi tersebut [3].

Dinamakan elemen hingga karena ukuran elemen kecil ini berhingga dan umumnya mempunyai bentuk geometri yang lebih sederhana dibandingkan kontinunya. Metode ini menjadi suatu solusi permasalahan yang sering dijumpai dalam dunia teknik seperti perpindahan kalor, mekanika fluida, analisis struktur, mekanika benda pejal, sampai dengan getaran. Tujuan utama analisis dengan menggunakan Metode Elemen Hingga adalah untuk memperoleh pendekatan tegangan dan perpindahan yang terjadi pada suatu struktur [4].

\section{METODOLOGI PENELITIAN}

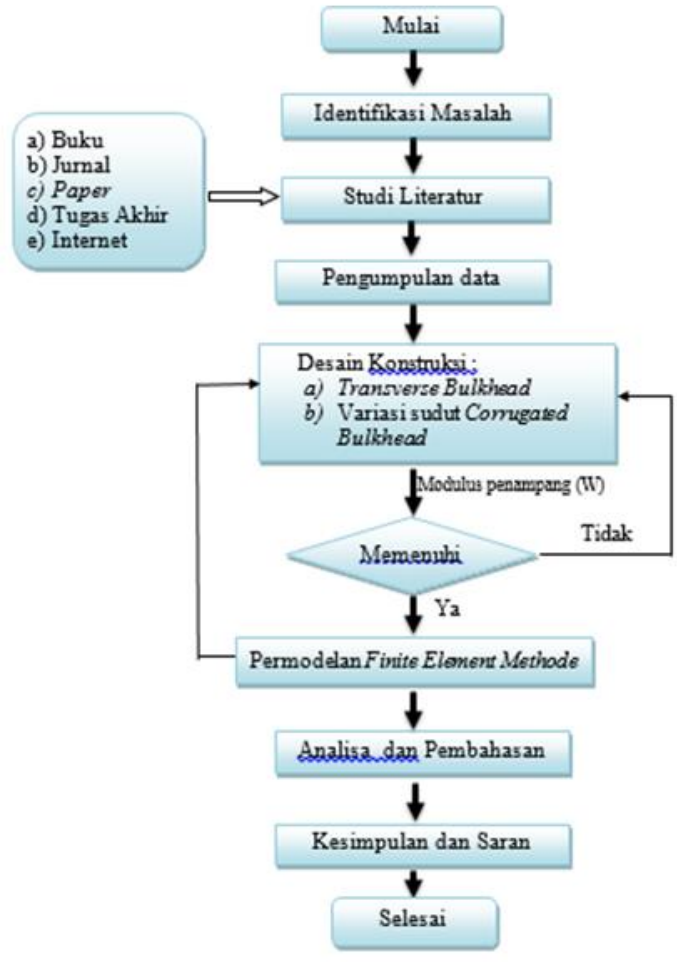

Gambar 4. Diagram Alir Motodologi Penelitian

\section{ANALISIS DAN PEMBAHASAN}

\section{A. Modulus Sekat Bergelombang}

Perhitungan modulus corrugated bulkhead dilakukan menggunakan aturan Biro Klasifikasi Indonesia tahun 2014 volume II adalah sebagai berikut:

$\mathrm{W}=\mathrm{t} \cdot \mathrm{d}(\mathrm{b}+\mathrm{s} / 3)$

dimana :

$$
\begin{aligned}
\mathrm{e} & =\text { lebar elemen }(\mathrm{cm}) \\
& =240 \mathrm{~cm} \\
\mathrm{~b} & =\text { lebar pelat hadap }(\mathrm{cm}) \\
& =84 \mathrm{~cm} \\
\mathrm{~s} & =\text { lebar pelat bilah }(\mathrm{cm}) \\
& =83.19 \mathrm{~cm} \\
\mathrm{~d} & =\text { jarak antara pelat hadap }(\mathrm{cm}) \\
& =75 \mathrm{~cm} \\
\mathrm{t} & =\text { tebal pelat }(\mathrm{cm}) \\
& =1.4 \mathrm{~cm}
\end{aligned}
$$

sehingga perhitungan modulus,

$$
\mathrm{W}=1,4 \times 75(84+83.19 / 3)
$$$$
\mathrm{W}=11731,381 \mathrm{~cm}
$$

\section{B. Perhitungan Variasi Sekat Bergelombang}

Variasi model sekat bergelombang (corrugated bulkhead) berdasarkan sudut berbeda maka dimensi elemen seperti lebar pelat hadap (b), jarak antara pelat hadap (d), pelat bilah (s), 
dan tebal pelat (t) akan berbeda juga. Perhitungan dimensi corrugated bulkhead berdasarkan sudut ini masih dalam satu modulus penampang dan panjang elemen yang mendekati atau sama dengan data awal.

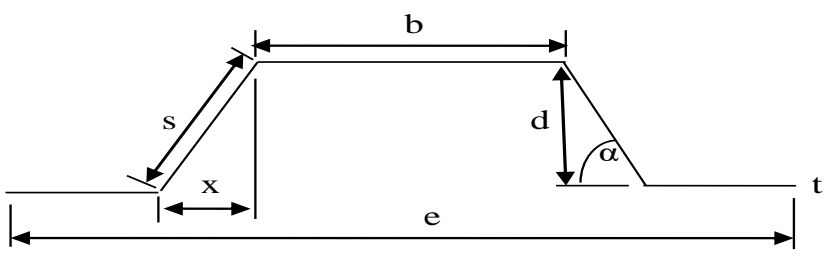

Gambar 5. Elemen Pada Variasi Corrugated Bulkhead

Ukuran sudut yang dipilih adalah Sudut $45^{\circ}, 55^{\circ}$, dan $65^{\circ}$ dan panjang elemen tetap yaitu $240 \mathrm{~cm}$.

Tabel. 1.

Dimensi Variasi Corrugated Bulkhead

\begin{tabular}{|c|c|c|c|c|}
\hline Sudut & 45 & 55 & 65 & $\begin{array}{c}64.36 \\
\text { (existing) }\end{array}$ \\
\hline Variasi tebal & 1.8 & 1.6 & 1.4 & 1.4 \\
\hline $\mathrm{x}=$ & 90 & 52.46 & 34.74 & 36 \\
\hline $\mathrm{s}=$ & 127.3 & 91.39 & 82.13 & 83.19 \\
\hline $\mathrm{b}=$ & 30 & 67.54 & 85.26 & 84 \\
\hline $\mathrm{d}=$ & 90.03 & 74.84 & 74.42 & 75 \\
\hline $\mathrm{e}=$ & 240 & 240 & 240 & 240 \\
\hline $\mathrm{W}=$ & 11737.66 & 11735.18 & 11735.04 & 11731.38 \\
\hline selisih (\%) & 0.054 & 0.032 & 0.031 & 0 \\
\hline
\end{tabular}

$\mathrm{cm}$

$\mathrm{cm}$

$\mathrm{cm}$

$\mathrm{cm}$

$\mathrm{cm}$

$\mathrm{cm}$

$\mathrm{cm}$

C. Perhitungan Sekat Melintang (Transverse Bulkhead)

Desain dimensi tranverse bulkhead ini dilakukan dengan acuan panjang elemen yang sama dengan corrugated bulkhead yaitu $240 \mathrm{~cm}$. Berdasarkan panjang elemen corrugated bulkhead maka terdapat beberapa penegar untuk transverse bulkhead yang jumlah modulusnya sama dengan nilai modulus data corrugated.

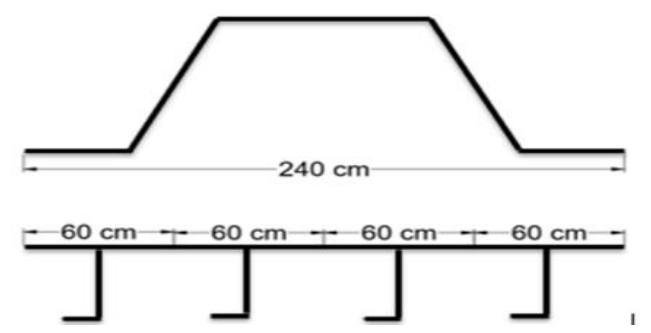

Gambar 6. Konversi Panjang Elemen Sekat

\section{1) Modulus Penegar}

Perhitungan modulus dilakukan dengan membagi modulus data corrugated bulkhead dengan beberapa penegar pada transverse bulkhead. Sehingga didapatkan nilai modulus penegar adalah $2932.845 \mathrm{~cm}^{3}$ selanjutnya dilakukan perhitungan ukuran profil penegar yang digunakan pada transverse bulkhead.

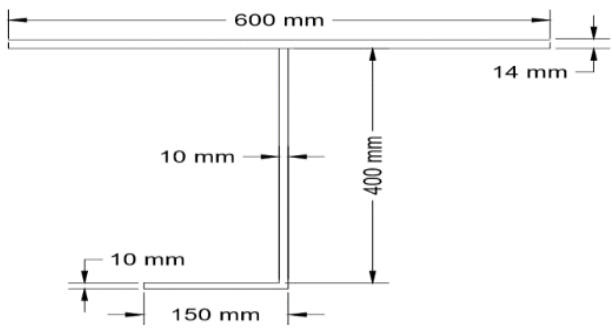

Gambar 7. Profil Penegar

Jenis profil penegar yang digunakan adalah profil $\mathrm{L}$ dimensi $400 \times 150 \times 10 \mathrm{~mm}$ dengan modulus $2963.821 \mathrm{~cm}^{3}$ dan selisih $1.056 \%$ dari modulus penegar awal.

\section{2) Modulus Penuтри}

Sehingga perhitungan modulus penampang untuk penumpu adalah sebagai berikut:

$\mathrm{W}=\mathrm{c} \cdot \mathrm{e} \cdot 12 \cdot \mathrm{p} \cdot \mathrm{k} \quad\left[\mathrm{cm}^{3}\right]$

dimana,

$$
\begin{aligned}
\mathrm{c} & =0,55 \\
\mathrm{e} \quad & =(1 \text { penegar atas }) /(2)+(1 \text { penegar bawah }) / 2) \\
& =6,09 /(2)+4,06 /(2)=5,075 \mathrm{~m} \\
\mathrm{~L} & =12,35 \mathrm{~m} \\
\mathrm{H} & =7.575 \mathrm{~m} \\
\mathrm{p} \quad & =9.81 \times 7,575=74,31 \mathrm{~cm}^{3} \\
\text { Reh } & =235 \\
\mathrm{k} \quad & =235 / 235=1 \\
\text { hingga } & \\
\mathrm{W} & =0.55 \times 5.075 \times 12.352 \times 74.31 \times 1 \\
& =31168.669 \mathrm{~cm}^{3}
\end{aligned}
$$

Sehingga,

Perhitungan lebar efektif pelat pengikut untuk penumpu.

Tabel. 2.

\begin{tabular}{l|lll}
\multicolumn{5}{c}{ Tabel. 2. } \\
Interpolasi lebar pelat efektif \\
\hline \hline l/e & 2 & $\mathbf{2 . 4 7}$ & 3 \\
& & & \\
$\mathrm{e}_{\mathrm{m} 2} / \mathrm{e}$ & 0.37 & $\mathbf{0 . 4 4}$ & 0.52 \\
\hline \hline
\end{tabular}

$1 / \mathrm{e}, 2.47=\mathrm{em} 2 / \mathrm{e} 0.44$

$$
\begin{aligned}
\mathrm{e}_{\mathrm{m} 2} & =\mathrm{e} \times 0.044 \\
& =5.075 \times 0.44 \\
& =2.203 \mathrm{~m}
\end{aligned}
$$

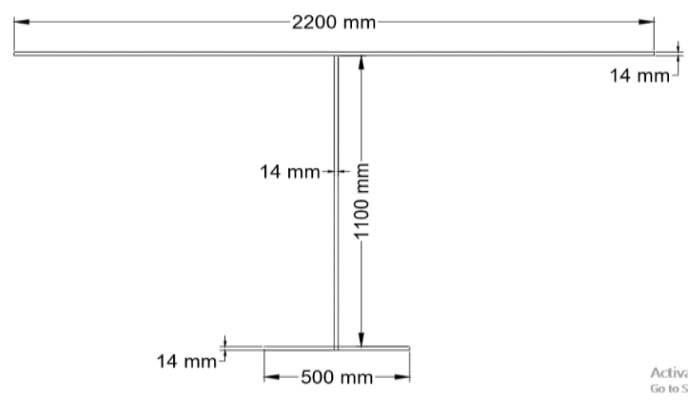

Gambar 8. Profil Penumpu 
Jenis profil penumpu yang digunakan adalah profil $\mathrm{T}$ dimensi 1100 x 500 x $14 \mathrm{~mm}$ dengan modulus 32093.2246 $\mathrm{cm}^{3}$ dan selisih $2.97 \%$ dari modulus penumpu awal

\section{Beban}

Perhitungan beban menggunakan aturan common structural rules for double hull oil tankers [5].

Tekanan statis yang terjadi pada tangki :

Pin-tk $=$ p.g.ztk $\mathrm{kN} / \mathrm{m}^{2}$

$$
\begin{aligned}
& \text { ztk } \quad=5.075 \\
& \rho \quad=0.9 \text { untuk fluida pada kekuatan lelah } \\
& 1.025 \text { untuk lainnya, dalam ton } / \mathrm{m} 3 \\
& \text { g } \quad=9.81 \mathrm{~m} / \mathrm{s}^{2}
\end{aligned}
$$

Tekanan statis tangki ketika pengisian penuh atau pengisian selama penggantian air ballast :

Pin-air = psw.g.zair kN/m²

Dimana :

$$
\begin{array}{ll}
\text { zair } & =7.575 \mathrm{~m} \\
\rho & =1.025 \mathrm{ton} / \mathrm{m}^{3} \\
\mathrm{~g} & =9.81 \mathrm{~m} / \mathrm{s}^{2}
\end{array}
$$

Tes tekanan pada tangki, diambil nilai paling besar dengan persyaratan dibawah ini :

Pin-test $=\rho s w . g . z t e s t \quad \mathrm{kN} / \mathrm{m}^{2}$

Pin-test $=\rho s w . g . z t e s t+$ Pvalve $\mathrm{kN} / \mathrm{m}^{2}$

Dimana :

$$
\begin{aligned}
& \text { ztest = a) } 7.575 \mathrm{~m} \\
& \text { b) } 5.075 \mathrm{~m} \\
& \rho=1.025 \text { ton } / \mathrm{m}^{3} \\
& \text { g } \quad=9.81 \mathrm{~m} / \mathrm{s}^{2} \\
& \text { Pvalve }=14 \mathrm{kN} / \mathrm{m}^{2}
\end{aligned}
$$

Berdasarkan perhitungan tekanan statis tangki dipilih nilai tekanan terjadi pada hasil pengujian tekanan (testing pressure) yaitu $76.169 \mathrm{kN} / \mathrm{m}^{2}$.

Tabel. 3.

Hasil Perhitungan Beban

\begin{tabular}{l|ll}
\hline & \multicolumn{2}{|c}{ Hasil Perhitungan Beban } \\
\hline \hline & $\mathrm{z}_{\text {tk }}(\mathrm{m})$ & $\mathrm{P}_{\text {in-tk }}\left(\mathrm{kN} / \mathrm{m}^{2}\right)$ \\
Cargo Tank & 5.075 & 44.807 \\
Ballast Trought & $\mathrm{Z}_{\text {air }}(\mathrm{m})$ & $\mathrm{P}_{\text {in-air }}\left(\mathrm{kN} / \mathrm{m}^{2}\right)$ \\
Exchange & 7.575 & 76.169 \\
& $\mathrm{z}_{\text {test }}(\mathrm{m})$ & $\mathrm{P}_{\text {in-test }}\left(\mathrm{kN} / \mathrm{m}^{2}\right)$ \\
& 7.575 & $\mathbf{7 6 . 1 6 9}$ \\
Testing Pressure & $\mathrm{z}_{\text {tk }}(\mathrm{m})$ & $\mathrm{P}_{\text {in-test }}\left(\mathrm{kN} / \mathrm{m}^{2}\right)$ \\
& 5.075 & 65.030 \\
\hline \hline
\end{tabular}

Beban diaplikasian sesuai tekanan hidrostatis muatan dimana beban yang berada pada bawah sekat paling besar dan semakin keatas semakin kecil.

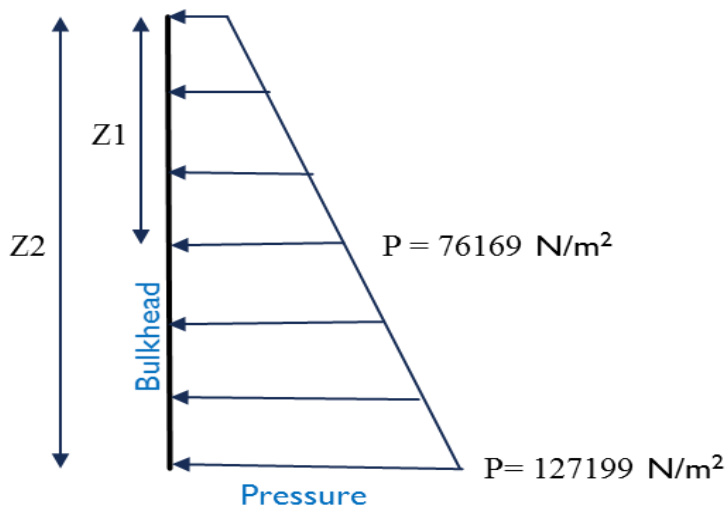

Gambar 9. Aplikasi Pembebanan Pada Sekat

\section{E. Hasil Analisis}

Hasil analisis sekat melintang menggunakan finite element software berupa tegangan von mises pada masing- masing model sekat. Didapatkan hasil sebagai berikut:

\section{1) Corrugated bulkhead sudut $45^{\circ}$}

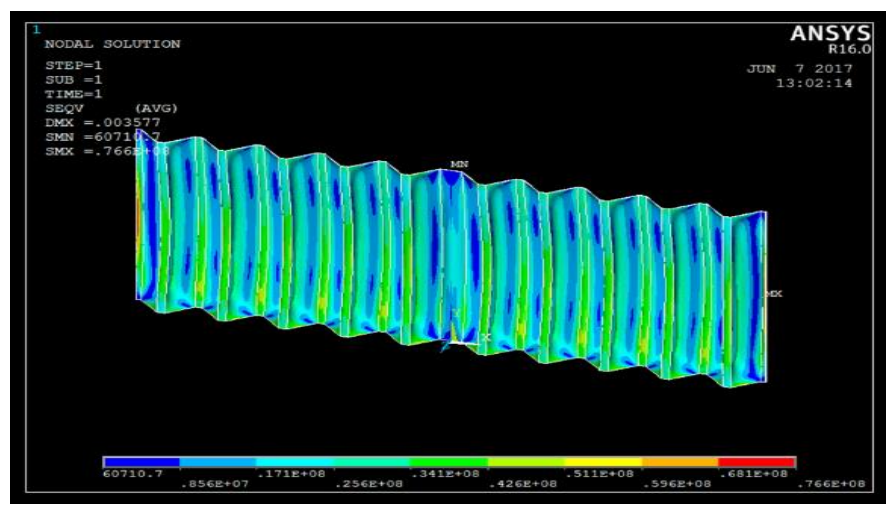

Gambar 10. Tegangan Pada Corrugated Bulkhead Sudut $45^{\circ}$

Nilai tegangan maksimum yang terjadi pada corrugated bulkhead sudut $45^{\circ}$ adalah $76.6 \mathrm{~N} / \mathrm{mm}^{2}$ berada pada sisi samping sekat.

\section{2) Corrugated bulkhead sudut $55^{\circ}$}

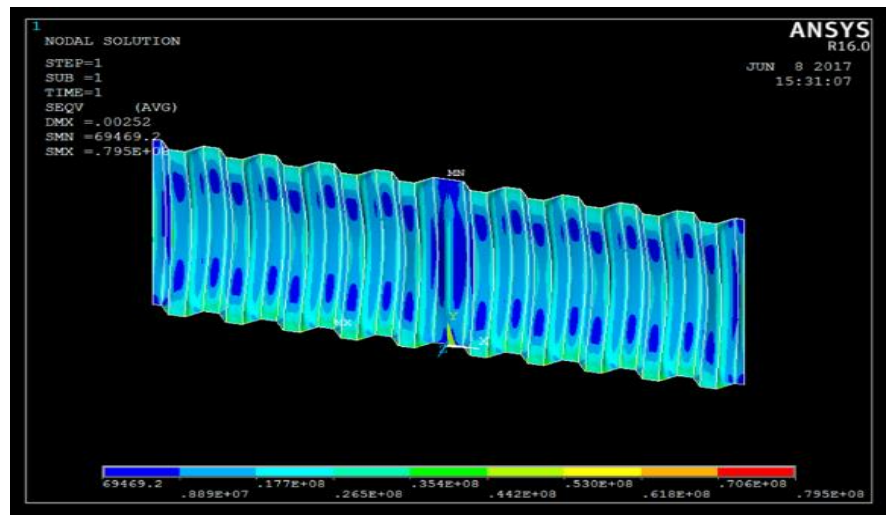

Gambar 11. Tegangan Pada Corrugated Bulkhead Sudut $55^{\circ}$

Nilai tegangan terbesar pada corrugated bulkhead sudut $55^{0}$ adalah $79.5 \mathrm{~N} / \mathrm{mm}^{2}$ yang berada pada daerah paling bawah sekat 


\section{3) Corrugated bulkhead Existing}

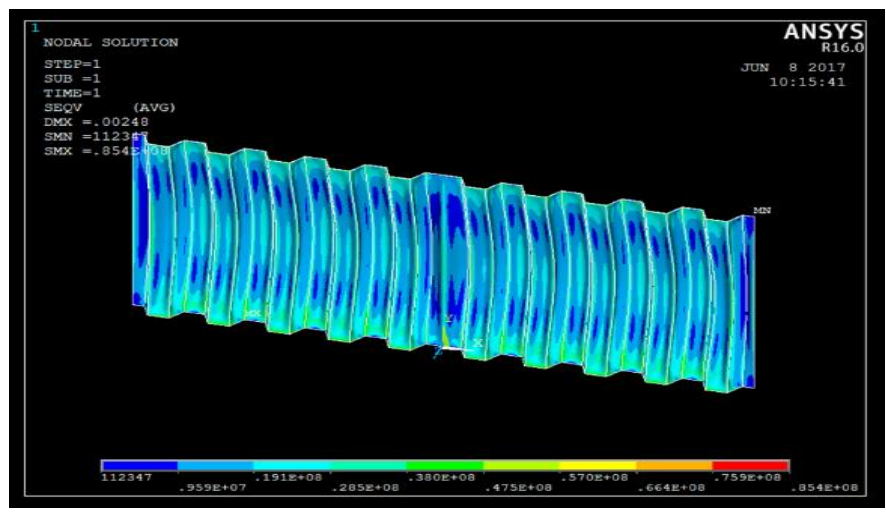

Gambar 12. Tegangan Pada Corrugated Bulkhead Sudut Existing

Nilai tegangan maksimum pada corrugated bulkhead existing adalah $85.4 \mathrm{~N} / \mathrm{mm}^{2}$ berada pada bagian alas sekat.

\section{4) Corrugated bulkhead sudut $65^{\circ}$}

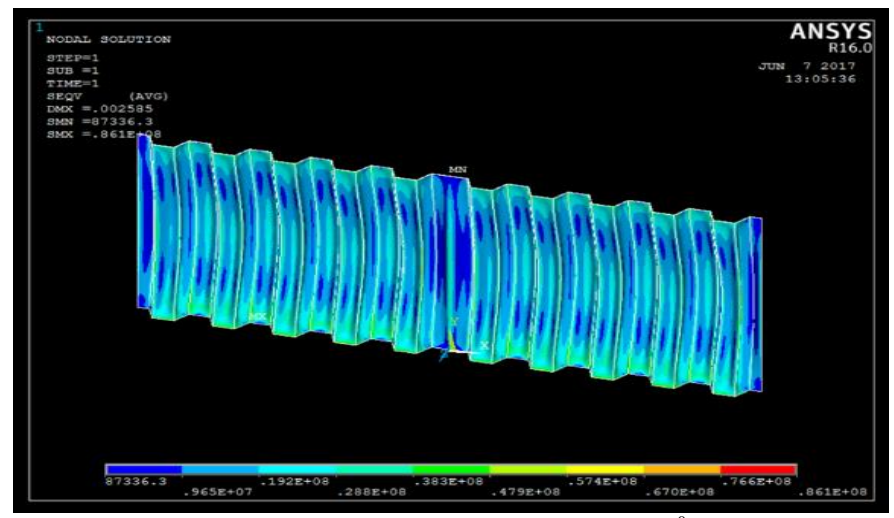

Gambar 13. Tegangan Pada Corrugated Bulkhead Sudut $65^{\circ}$

Nilai tengangan maksimum pada corrugated bulkhead $65^{\circ}$ adalah $86.1 \mathrm{~N} / \mathrm{mm}^{2}$ berada pada bagian alas sekat.

5) Transverse bulkhead sudut dengan penuтри

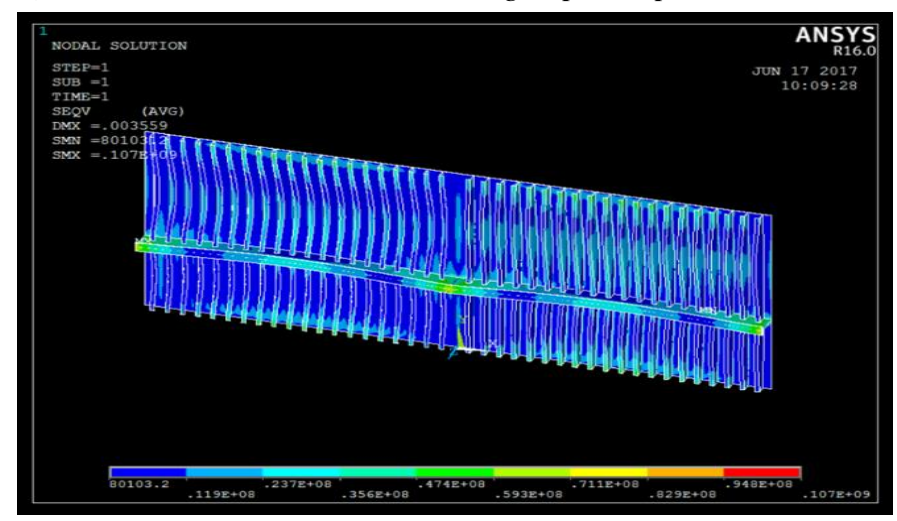

Gambar 14. Tegangan Pada Transverse Bulkhead Dengan Penumpu

Nilai tegangan terbesar pada Transverse bulkhead dengan penumpu adalah $107 \mathrm{~N} / \mathrm{mm}^{2}$ yang berada pada penegar bagian sisi sekat dengan tumpuan beban.

\section{6) Transverse bulkhead sudut dengan penumpu}

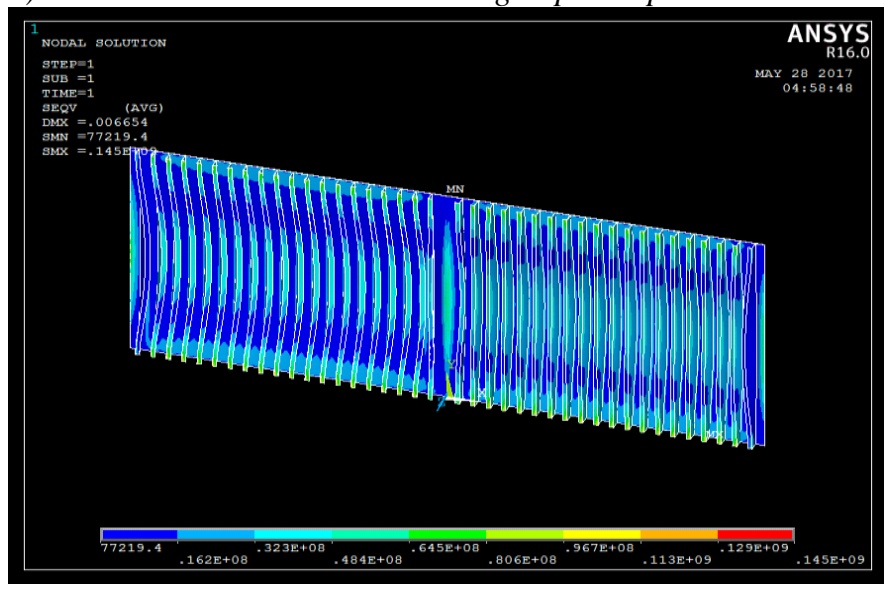

Gambar 15. Tegangan Pada Transverse Bulkhead Tanpa Penumpu

Tegangan terbesar pada transverse bulkhead tanpa penumpu berada pada bagian paling bawah sekat yaitu 145 $\mathrm{N} / \mathrm{mm}^{2}$, nilai tegangan minimum berada pada bagian paling atas sekat.

Tabel. 4.

Nilai Tegangan Masing-Masing Model Sekat

\begin{tabular}{|l|c|c|c|}
\hline \multicolumn{1}{|c|}{ Model Sekat Melintang } & $\begin{array}{c}\text { Tegangan } \\
\text { Maksimum } \\
\left(\mathbf{N} / \mathbf{m m}^{2}\right)\end{array}$ & $\begin{array}{c}\text { Tegangan } \\
\text { Ijin } \\
\left(\mathbf{N} / \mathbf{m m}^{2}\right)\end{array}$ & $\sigma_{\text {maks }} \leq \sigma_{\text {ijin }}$ \\
\hline Corrugated bulkhead sudut 45 & 76.6 & 180 & memenuhi \\
\hline Corrugated bulkhead sudut 55 & 79.5 & 180 & memenuhi \\
\hline $\begin{array}{l}\text { Corrugated bulkhead sudut } \\
\text { 64.36 (existing) }\end{array}$ & 85.4 & 180 & memenuhi \\
\hline Corrugated bulkhead sudut 65 & 86.1 & 180 & memenuhi \\
\hline $\begin{array}{l}\text { Tranverse Bulkhead dengan } \\
\text { penumpu }\end{array}$ & 107 & 180 & memenuhi \\
\hline $\begin{array}{l}\text { Tranverse Bulkhead tanpa } \\
\text { penumpu }\end{array}$ & 145 & 180 & memenuhi \\
\hline
\end{tabular}

Hasil analisis sekat melintang menggunakan finite element software berupa deformasi pada masing- masing model sekat. Didapatkan hasil sebagai berikut:

Tabel. 5.

Nilai Deformasi Masing-Masing Model Sekat

\begin{tabular}{|l|c|}
\hline \multicolumn{1}{|c|}{ Model Sekat Melintang } & Deformasi \\
\hline Corrugated bulkhead sudut 45 & 3.58 \\
\hline Corrugated bulkhead sudut 55 & 2.52 \\
\hline Corrugated bulkhead data & 2.48 \\
\hline Corrugated bulkhead sudut 65 & 2.58 \\
\hline Tranverse Bulkhead dengan penumpu & 3.56 \\
\hline Tranverse Bulkhead tanpa penumpu & 6.64 \\
\hline
\end{tabular}

F. Pembahasan

1) Tegangan

Nilai tegangan paling tinggi terdapat pada model sekat transverse bulkhead tanpa penumpu yaitu $145 \mathrm{~N} / \mathrm{mm}^{2}$ dan 
nilai tegngan terendah terdapat pada model corrugated bulkhead sudut $45^{0}$ yaitu $76.6 \mathrm{~N} / \mathrm{mm}^{2}$.

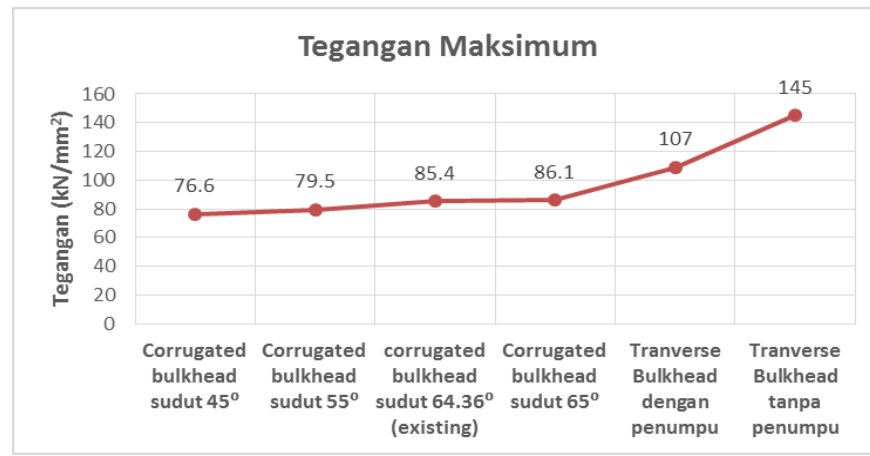

Gambar 16. Grafik Perbedaaan Nilai Tegangan

\section{2) Deformasi}

Nilai deformasi terkecil berada pada konstruksi sekat corrugated bulkhead existing yaitu $2.48 \mathrm{~mm}$ dan nilai deformasi terbesar berada pada model transverse bulkhead tanpa penumpu yaitu $6.64 \mathrm{~mm}$.

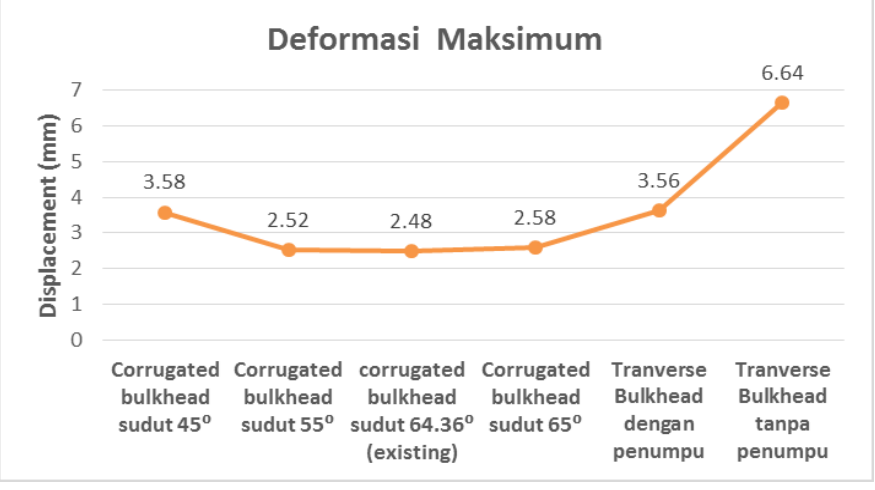

Gambar 17. Grafik Perbedaan Deformasi

\section{3) Berat Konstruksi}

Tabel 6 .

Perhitungan Berat Corrugated Bulkhead

\begin{tabular}{|c|c|c|c|c|c|c|c|c|c|c|}
\hline \multirow[b]{2}{*}{ No } & \multirow{2}{*}{$\begin{array}{l}\text { Transverse } \\
\text { bulkhead }\end{array}$} & \multicolumn{3}{|c|}{ Ukuran (m) } & \multirow[b]{2}{*}{ Area $m^{2}$} & \multirow{2}{*}{$\begin{array}{l}\text { Tinggi } \\
\text { (m) }\end{array}$} & \multirow{2}{*}{$\begin{array}{c}\text { Volume } \\
\mathrm{m}^{3}\end{array}$} & \multirow{2}{*}{$\begin{array}{c}\text { Massa } \\
\text { jenis } \\
\left(\mathrm{kg} / \mathrm{m}^{3}\right)\end{array}$} & \multirow[b]{2}{*}{ Jumlah } & \multirow[b]{2}{*}{ Berat $(\mathrm{kg})$} \\
\hline & & Panjang & Lebar & tebal & & & & & & \\
\hline 1 & pelat sekat & 24.7 & 10.15 & 0.014 & - & - & 3.51 & 7850 & 1 & 27552.48 \\
\hline 2 & penegar & 0.4 & 0.15 & 0.01 & 0.006 & 10.15 & 0.056 & 7850 & 40 & 17529.05 \\
\hline 3 & penumpu & 1.1 & 0.5 & 0.014 & 0.022 & 24.7 & 0.553 & 7850 & 1 & 4343.25 \\
\hline & & & & & & Finsv & tokn & enzan & pu $=$ & \begin{tabular}{|l|l}
4924.78 \\
\end{tabular} \\
\hline
\end{tabular}

Tabel 7.

Perhitungan Berat Transverse Bulkhead

\begin{tabular}{|c|l|c|c|c|c|c|c|c|c|c|}
\hline \multirow{2}{*}{ No } & \multirow{2}{*}{$\begin{array}{c}\text { Corrugated } \\
\text { bulkhead }\end{array}$} & \multicolumn{3}{|c|}{ Ukuran $(\mathrm{m})$} & jumlah & Area $\mathrm{m}^{2}$ & $\begin{array}{c}\text { Tinggi } \\
(\mathrm{m})\end{array}$ & $\begin{array}{c}\text { Volume } \\
\left(\mathrm{m}^{3}\right)\end{array}$ & $\begin{array}{c}\text { Massa } \\
\text { jenis } \\
\left(\mathrm{kg} / \mathrm{m}^{3}\right)\end{array}$ & $\begin{array}{c}\text { Berat } \\
(\mathrm{kg})\end{array}$ \\
\cline { 3 - 13 } & & $\mathrm{b}$ & $\mathrm{s}$ & tebal & & & & \\
\hline 1 & sudut $45^{0}$ & 0.3 & 1.27 & 0.018 & 10 & 0.578 & 10.15 & 5.865 & 7850 & 46037.7 \\
\hline 2 & sudut $55^{0}$ & 0.675 & 0.914 & 0.016 & 10 & 0.52 & 10.15 & 5.275 & 7850 & 41406.8 \\
\hline 3 & sudut $64.36^{0}$ & 0.84 & 0.832 & 0.014 & 10 & 0.478 & 10.15 & 4.851 & 7850 & 38082.7 \\
\hline 4 & sudut $65^{0}$ & 0.853 & 0.821 & 0.014 & 10 & 0.479 & 10.15 & 4.857 & 7850 & 38127.3 \\
\hline
\end{tabular}

Pada corrugated bulkhead berat konstruksi terbesar berada pada model dengan sudut 450 yaitu sebesar 46.03 ton dan berat terkecil berada pada model existing yaitu sebesar 38.08 ton.

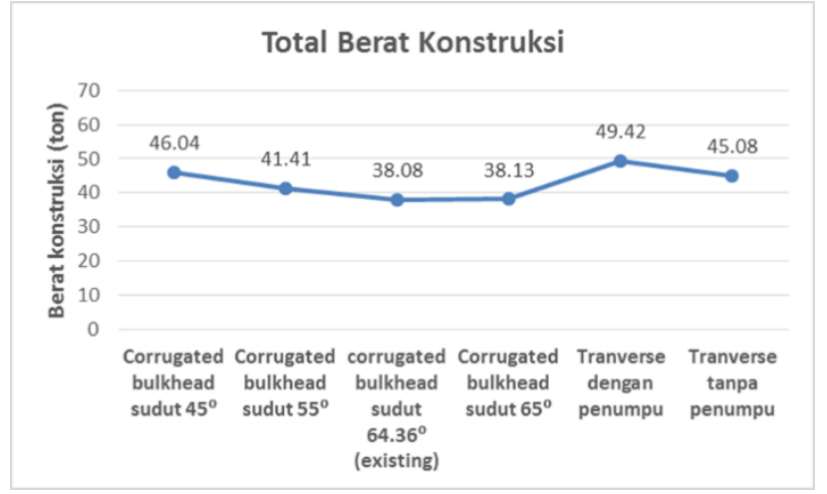

Gambar 18. Grafik Total Berat Konstruksi Sekat

Berat total konstruksi pada masing masing sekat akan mempengaruhi total harga untuk suatu konstruksi sekat sehingga dilakukan perbandingan dengan untuk mengetahui kekuatannya.

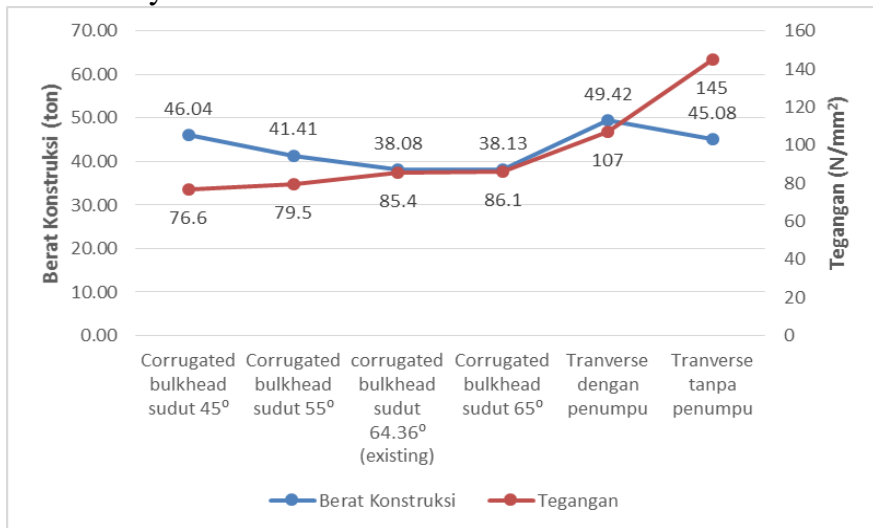

Gambar 19. Grafik Perbandingan Berat Konstruksi Dan Tegangan

Hasil berat konstruksi dan tegangan pada corrugated bulkhead sudut 64.360 (existing) memiliki berat yang paling kecil yaitu 38.08 ton dan nilai tegangan sebesar 85.4 $\mathrm{N} / \mathrm{mm}^{2}$ sehingga pada konstruksi sekat ini merupakan nilai optimal pada sekat melintang.

\section{KESIMPULAN}

1. Perhitungan modulus pada transverse bulkhead dengan penjumlahan beberapa modulus penegar sesuai panjang elemen serta modulus corrugated bulkhead.

2. Dimensi profil penegar adalah $400 \times 150 \times 10 \mathrm{~mm}$ dan penumpu $=1100 \times 500 \times 14 \mathrm{~mm}$.

3. Tegangan terkecil pada corrugated bulkhead sudut $45^{\circ}$ yaitu $76.6 \mathrm{~N} / \mathrm{mm}^{2}$ dan terbesar pada transverse bulkhead tanpa penumpu $=145 \mathrm{~N} / \mathrm{mm}^{2}$.

4. Deformasi terkecil pada corrugated bulkhead existing yaitu $2.48 \mathrm{~mm}$ dan terbesar pada transverse bulkhead tanpa penumpu $=6.64 \mathrm{~mm}$.

5. Berat konstruksi, terkecil pada corrugated bulkhead existing $=38.1$ ton, terbesar pada transverse bulkhead tanpa penumpu yaitu 49.5 ton.

6. Konstruksi sekat yang paling murah adalah corrugated bulkhead existing dengan nilai tegangan $85.4 \mathrm{~N} / \mathrm{mm}^{2}$ yang memenuhi tegangan ijin. 


\section{DAFTAR PUSTAKA}

[1] P. B. K. Indonesia, Rules for The classification and Construction of Sea going Steel Ship Volume II : Rules for Hull. Jakarta, 2014.

[2] D. I. Kusna, Teknik Konstruksi Kapal Baja. Direktorat Pembinaan Sekolah Menegah Atas Departemen Pendidikan Nasional, 2008.

[3] R. . Cook, Konsep dan Aplikasi Metode Elemen Hingga. Bandung: PT ERESCO, 1990.

[4] P. . Weaver .W.Jr., Johnston, Elemen Hingga Untuk Analisis Struktur Edisi kedua. Bandung, 1993.

[5] IACS, Common Structural Rules for Double Hull Oil Tankers. United Kingdom: IACS, 2012. 